\title{
Yield and its attributes responses of drought tolerant upland 'NERICA' rice to different nutrient supplying treatments in rainforest transitory agroecology
}

\author{
*Olalekan SAKARIYAWO ${ }^{1}$, Mufutau ATAYESE ${ }^{1}$, Kehinde OKELEYE $^{1}$, Abimbola BABALOLA $^{2}$, Idowu \\ ADEGOKE $^{1}$, Michael DARE ${ }^{2}$, Paul SOREMI ${ }^{1}$, Sunday ADIGBO ${ }^{3}$
}

Received January 22, 2016; accepted November 24, 2016.

Delo je prispelo 22. januarja 2016, sprejeto 24. novembra 2016.

\begin{abstract}
A screen house trial was conducted to evaluate reproductive growth responses of drought tolerant upland rice cultivars (NERICAs 1-4, WAB 56-104 and Moroberekan) to arbuscular mycorrhizal (AMF) inoculation under water deficit. A field trial was organized in randomized complete block test with three replicates, conducted in the late cropping season of 2012. We evaluated upland rice cultivars to different nutrient sources (AMF, AMF + $60 \mathrm{~kg} \mathrm{~N} \mathrm{ha}^{-1}+30 \mathrm{~kg} \mathrm{~K} \mathrm{ha}^{-1}, 60 \mathrm{~kg} \mathrm{~N}$ $\mathrm{ha}^{-1}+30 \mathrm{~kg} \mathrm{~K} h a^{-1}$ and control). In the screen house inoculated rice had higher $(P<0.05)$ grain yield plant ${ }^{-1}\left(19.29\right.$ g plant $\left.^{-1}\right)$ and its attributes than non-inoculated, except number of grain per panicle (108). On the field combination of AMF $+60 \mathrm{~kg} \mathrm{~N}$ $\mathrm{ha}^{-1}+30 \mathrm{~kg} \mathrm{~K} \mathrm{ha}^{-1}$ produced higher $(P<0.05)$ reproductive growth. Varietal variability $(P<0.05)$ was observed on AM colonisation and reproductive growth in both trials, with 'NERICA 2'was the most promising cultivar under tested agroecology condition.
\end{abstract}

Key words: arbuscular mycorrhizae; rainforest transitory agroecology; root colonization; reproductive growth
IZVLEČEK

\author{
ODZIV PRIDELKA NA SUŠO ODPORNIH SORT \\ NENAMAKANEGA RIŽA 'NERICA' IN \\ PARAMETROV PRIDELKA NA RAZLIČNA \\ OBRAVNAVANJA S HRANILI V AGROEKOLOŠKIH \\ RAZMERAH PREHODA V DEŽEVNI GOZD
}

Za ovrednotenje odziva na inokulacijo $\mathrm{z}$ arbuskolarnimi mikoriznimi glivami (AMF) na izbrane sorte nenamakanega, na sušo odpornega riža ('NERICAs 1-4', 'WAB 56-104' in 'Moroberekan') v reproduktivni rastni fazi, sta bila izvedena lončni poskus $\mathrm{v}$ rastlinjaku in poljski poskus $\mathrm{v}$ razmerah pomanjkanja vode. Poljski poskus je bil izveden kot popolni bločni poskus s tremi ponovitvami v pozni rastni sezoni 2012. Sorte nenamakanega riža so bile ovrednotene glede na različna obravnavanja s hranili (AMF, AMF + $60 \mathrm{~kg} \mathrm{~N} \mathrm{ha}^{-1}+30 \mathrm{~kg} \mathrm{~K}$ $\mathrm{ha}^{-1}, 60 \mathrm{~kg} \mathrm{~N} \mathrm{ha}^{-1}+30 \mathrm{~kg} \mathrm{~K} \mathrm{ha}^{-1}$ in kontrola). V lončnem poskusu v rastlinjaku je imel inokuliran riž večji pridelek zrnja na rastlino $\left(P<0.05,19.29 \mathrm{~g}\right.$ rastlino $\left.^{-1}\right)$, večji so bili tudi drugi parametri pridelka kot pri neinokuliranem, z izjemo števila zrn na lat (108). V poljskem poskusu je obravnavanje AMF + $60 \mathrm{~kg} \mathrm{~N} \mathrm{ha}{ }^{-1}+30 \mathrm{~kg} \mathrm{~K}^{-1}$ hzpobudilo večjo $(P<0.05)$ reproduktivno rast. Razlika med sortami $(P<0.05)$ je bila opažena tako $\mathrm{v}$ kolonizaciji $\mathrm{z}$ arbuskularnimi glivami kot $\mathrm{v}$ reproduktivni rasti v obeh poskusih. Sorta NERICA 2 se je izkazala kot najobetavnejša $\mathrm{v}$ preiskušenih agroekoloških razmerah.

Ključne besede: arbuskularna mikoriza; agroekološke razmere; prehod v deževni gozd; kolonizacija korenin; reproduktivna rast

\footnotetext{
1 Department of Plant Physiology and Crop Production, Federal University of Agriculture, Abeokuta (FUNAAB), P.M.B. 2240.Alabata, Ogun State, Nigeria; * Corresponding author: adetanwa@yahoo.co.uk

2 Department of Soil Science and Land Management, FUNAAB, P.M.B. 2240, Alabata, Ogun State, Nigeria

3 Institute of Food Security, Environmental Resources and Agricultural Research (IFSERAR), FUNAAB, Nigeria
} 


\section{INTRODUCTION}

The production of the upland rice in the tropics has been on the rise in terms of area under cultivation in recent years. Area under upland rice production in Nigeria according to Oikeh et al.(2008) constituted only $25 \%$ of the total area under rice production. Though comparatively, grain yield of upland rice is lesser than that of the lowland rice, however the issue of sustainability in the face of climate change has necessitated a rethink in the production technology of rice in particular. Conventionally, lowland rice production demands usage of fresh water. With uneven rainfall pattern occasioned by climate change limiting the availability of fresh water (Fjelde and von Uexkull, 2012), there is a need for more sustainable water management. This is where upland rice production technology provides an alternative perspective.

Exploitation of the upland rice production ecology could only be feasible if the problem of soil moisture deficit is adequately addressed, especially at the reproductive growth stage. Improvement of rice performance could be done through genetic improvements, cultural management or both approaches. In most rice growing areas of subSahara Africa, Oryza sativa L. cultivars are very popular due to their high productivity. However, they are highly susceptible to a wide range of deteriorating abiotic and biotic environmental factors (Jones, 1997; Jones et al., 1997). The native Oryza glaberrima Steud. is more resistant to a wide range of abiotic and biotic environmental factors than $O$. sativa but with lesser performance (Linares, 2002). It was in the light of this that AfricaRice, the umbrella research and development organisation mandated to research into rice value chain in Africa introduced interspecific varieties of rice (NERICA), combining high productivity of $O$. sativa and the hardiness of $O$. glaberrima (Defoer et al., 2004). Arbuscular mycorrhizae fungi (AMF) form a symbiotic relationship with most agricultural crops. Extensive report had been made on their nutritional effect on most crops especially phosphorus uptake in marginal soils (Smith and Read, 2008). Other reports had equally cited their effect on plant water status (Augé, 2001;Augé, 2004). The confounding effect of nutrient uptake on water status of inoculated crops though difficult to disentangle, the positive effect of AMF inoculation on crop water status remains a subject of intensive debate in the literature (Boyeret al., 2014; Jayne and Quigley, 2013; Rapparini and Peñuelas, 2014). Inoculation with AMF was reported to have significant effect on both soil (Augé, 2004) and water status (Augé, 2001). It was indicated that improved soil water potential could have been mediated through its effect on the formation of glomalin (Rillig, 2004) and stability of soil aggregates (Miller and Jastrow, 1994). On the crop the possibilities of AMF colonisation altering hydraulic properties of the root and leaf have been reported (Koide et al., 1989), though the results were inconsistent over several crop species. Other non-hydraulic effects had also been reported. These responses could affect leaf gas exchange parameters (Awotoye et al., 1992), nutrient uptake (Franson et al., 1991) and consequently grain yield.

Most reports on the positive effect of AMF colonisation were cited on marginal soil fertility (Hayman et al., 1975). There were conflicting perspectives on the combination of nutrient sources on the activity of AMF in the literature. Root colonisation of the host plant was reported to be a function of nutrient status of the soil (Liu et al., 2000) and that of the host (Ratnayake et al., 1978). Abbott et al. (1984) indicated that a high P status of the soil reduced host root colonisation by AMF. A converse pattern was reported for $\mathrm{N}$ and $\mathrm{K}$ (Furlan and Bernier-Cardou, 1989; Sylvia and Neal, 1990). Different combinations of N, P and K were investigated in the literature on root colonisation by AMF (Azcón et al., 1978; Sumner and Farina, 1986) with inconsistent results depending on the host and location where the investigation was conducted. There is also paucity of information on the genotypic differences of some upland rice cultivars on percentage AMF colonisation at different growth stages in the rainforest transitory ecology. Since rice crop is susceptible mostly to water deficit at reproductive growth stage, we hypothesised that increased root colonisation at such a stage would confer some level of drought tolerance on 'NERICA' rice.

This investigation was conducted to investigate the effect of AMF inoculation of some upland NERICA rice cultivars under soil water stress on AMF root colonisation and reproductive growth. We equally aimed to explicate the effect of 
combination of different nutrient sources on AMF root colonisation and reproductive growth of these upland rice cultivars in the transitory rainforest.

\section{MATERIALS AND METHODS}

Two experiments (pot and field) were conducted.

\subsection{Description of pot experiment}

A pot experiment was conducted in the screen house of the College of Plant Science and Crop Production, FUNAAB in May, 2012. The pot experiment had a $6 \times 2 \times 2$ factorial treatment structure, which was laid out in a complete randomised design (CRD) with three replicates. Six varieties of upland rice were used ('NERICA 1', 'NERICA 2', 'NERICA 3', 'NERICA 4', 'WAB 56-104' and 'Moroberekan'), inoculated and un-inoculated with AMF with two stress status (water stressed and control).

Before planting, the soil was maintained to $100 \%$ field capacity using the gravimetric method. Seeds were planted in pots $(10 \mathrm{~kg}$ capacity), filled to three quarter with sandy loam soil. Two to three seeds of each variety were planted per hole to a depth of about 2-3 cm and $50 \mathrm{~g}$ of AMF inoculum was applied at the base of the seeds during planting. The plants were thinned to one plant per stand ten days after sowing (DAS). The pots were maintained to field capacity for 21 days after which moisture stress was imposed. At the seedling stage (sowing to mid-tillering), the amount of water supplied to the pots daily was determined through differences in mass at full field capacity and water loss to evapotranspiration, while at full canopy (vegetative to reproductive growth stage), supply of water was based on the degree of soil surface dryness as reported by Yoshida and Hasegawa, (1982). Soil moisture stress was imposed on all the six varieties except control, at 21 (DAS) (vegetative growth), 50 DAS (reproductive growth) and 70 DAS (grain filling). The duration of soil water deficit was 20 days at each growth stage. There after water was restored untill harvest maturity.

\subsection{Mycorrhizal inoculation}

The mycorrhizal fungi used in this study were Funneliformis mosseae (T.H. Nicolson \& Gerd.) C. Walker \& A. Schuessler strains (previously Glomus mosseae (T.H. Nicolson \& Gerd.) Gerd. \&
Trappe) isolated from rice farmers' field sampled across different agroecological zones of Nigeria. The inoculum was multiplied in the screen house for inoculum production using method described by Noyd, (1965). Pots were filled with $5 \mathrm{~kg}$ soil, with $5 \mathrm{~cm}$ hole made in the centre. A $30 \mathrm{~g}$ of pure inoculum of AMF species (Glomus mosseae) was applied to 2 seeds of maize per hole during planting, watered with sterilized $\mathrm{H}_{2} \mathrm{O}$ and placed in the screen house for four months. Sterilized $\mathrm{H}_{2} \mathrm{O}$ with $5 \mathrm{ml}$ of Hoagland's solution (Hoagland and Arnon, 1950) was applied every 2 days as source of irrigation. Watering of maize ceased just before commencement of heading. The maize plants were removed from the pot. The remaining root from severed crop and soil were carefully mixed and used as inoculum. Root samples were collected at 8 weeks after planting (WAP) to establish AMF colonization count. Modified wet sieving method of Giovannetti and Mosse, (1980) was used to extract spores from Quartz sand used for multiplication of spore while spores were counted using the dissecting microscope.

\subsection{Location and soil properties of the field experiment}

A field trial was conducted at the Teaching and Research Farm of FUNAAB, Alabata, Ogun State $\left(07^{\circ} 20^{\prime} \mathrm{N} ; 03^{\circ} 23^{\prime} \mathrm{E}\right)$ in the rainforest transitory agroecology of Nigeria. Soil particle size distribution was determined using the hydrometer method (Bouyoucos, 1962). The $\mathrm{pH}$ was determined (in 1: 1 soil: water) using a $\mathrm{pH}$ meter (glass electrode) (McLean, 1982). The organic content of the samples was determined using wet oxidation method Walkley and Black (1934) modified by Allison et al. (1965). Total nitrogen was determined using modified micro Kjeldahl digestion technique (Jackson, 1962). Available phosphorus was determined using Bray-1 (Olsen and Dean, 1965) and determined colometrically using the method of (Murphy and Riley, 1952). $\mathrm{K}^{+}$ in the extract was determined by flame photometry. The textural class of experimental site was sandy loam, with slightly acidic $\mathrm{pH}$ (6.4), of $0.52 \%$ organic matter content. The total $\mathrm{N}$ in the 
soil was $0.05 \%$, while that of $\mathrm{K}$ was $1.63 \mathrm{cmol} \mathrm{kg}^{-}$

${ }^{1}$. Available $\mathrm{P}$ in the soil was $38.8 \mathrm{mg} \mathrm{kg}^{-1}$.

\subsection{Treatments and design}

The field experiment was $6 \times 4$ factorial treatment structure, laid out in randomised complete block design (RCBD), with three replicates. Six upland rice varieties and four nutrient supplying treatments were used (+ AMF, AMF $+60 \mathrm{~kg} \mathrm{~N}$ ha ${ }^{1}+30 \mathrm{~kg} \mathrm{~K} \mathrm{ha}^{-1}, 60 \mathrm{~kg} \mathrm{~N} \mathrm{ha}^{-1}+30 \mathrm{~kg} \mathrm{~K} \mathrm{ha}^{-1}$ and a control). Three viable seeds were planted per hole and later thinned to one at the spacing of $0.2 \mathrm{~m} \times$ $0.2 \mathrm{~m}$, with a gross plot of $3 \mathrm{~m} \times 3 \mathrm{~m}\left(9 \mathrm{~m}^{2}\right)$ and a net plot of $2 \mathrm{~m} \times 3 \mathrm{~m}\left(6 \mathrm{~m}^{2}\right)$.

\subsection{Cultural practice}

The site of the field experiment was cleared, ploughed once and harrowed. The field was laid out into plot sizes of $3 \mathrm{~m} \times 3 \mathrm{~m}$. Planting was done in August/September, 2012, at seeding rate of 3 seeds per hole, in $0.2 \mathrm{~m} \times 0.2 \mathrm{~m}$ grid. AMF was applied at $50 \mathrm{~g}$ per hole at planting. Nitrogen and potassium fertiliser in the form urea $\left(60 \mathrm{~kg} \mathrm{~N} \mathrm{ha}^{-1}\right)$ and muriate of potash (MOP) (30 kg K ha $\left.{ }^{-1}\right)$, respectively was applied. Split application of nitrogen was conducted ( $1 / 2$ at planting and $1 / 2$ at panicle initiation).

\subsection{Sampling and measurements}

\section{Root sampling for AMF infection}

Fine root samples of rice cultivars were collected to estimate \% AMF colonisation. The root samples were washed with tap water, and cut into $1 \mathrm{~cm}$ length and $0.25 \mathrm{~g}$ of the selected fresh fine roots were taken, cleaned in $10 \%$ potassium hydroxide $(\mathrm{KOH})$ in water bath for 20-30 minutes at $80{ }^{\circ} \mathrm{C}$, then rinsed with water and stained with staining solution [methyl blue in lactoglycerol (1:1:1 lactic acid, glycerol and water)]placed in water bath for 2 minutes at $90{ }^{\circ} \mathrm{C}$ (Phillips and Hayman, 1970). The stained solution was rinsed off the roots and preserved with $50 \%$ glycerol solution for further observation under the compound microscope. Mycorrhizal infection was quantified using the magnified intersection method as described by (McGonigle et al. (1990). Five hills of rice plant per net plot were used for the determination of reproductive growth parameters. Yield and its components were determined according to Standard Evaluation System (International Rice Research Institute, 2002).

\subsection{Statistical analysis}

Data collected were subjected to Analysis of Variance (ANOVA), fixed model at $5 \%$ probability level. Discrete data were transformed using square root transformation before subjecting them to ANOVA. Other variables were checked for the violation of ANOVA assumptions prior to analysis. Significant means were separated using Standard Error of Differences (SED) and Duncan Multiple Range Test (DMRT). GenStat statistical package $12^{\text {th }}$ Edition was used for all the analysis.

\section{RESULTS}

At all growth stages, moisture stress status had no significant $(P>0.05)$ effect on percentage AM colonisation (Table 1). All crops inoculated with AMF had significantly $(P<0.05)$ higher percentage AM colonisation than those without inoculation across all growth stages. Significant $(P<0.05)$ varietal variability was observed on percentage AM colonisation at all growth stages. At all growth stages 'Moroberekan' had the least percentage AM colonisation except at reproductive, where 'NERICA 3' had the least AM colonisation $(18.83 \%)$. Conversely at vegetative growth stage 'NERICA 3' had significantly higher percentage infection $(45.3 \%)$ than other varieties. At reproductive growth stage 'NERICA 4' had significantly $(P<0.05)$ higher percentage infection $(35.29 \%)$ compared to others. At grain filling stage, it was observed that 'NERICA 1' had significantly $(P<0.05)$ higher percentage AM colonisation $(31.55 \%)$ relative to other varieties. 
Yield and its attributes responses ... rice to different nutrient supplying treatments in rainforest transitory agroecology

Table 1: Effect of moisture stress at different growth stages on \% AM colonization of upland 'NERICA' rice

\begin{tabular}{llll}
\hline Treatments & Vegetative phase & Reproductive phase & Grain-filling phase \\
\hline & & $\%$ AM colonisation & \\
\hline Stress status & & & \\
unstressed & 31.9 & 23.13 & 25.68 \\
stressed & 34.3 & 26.98 & 25.38 \\
& NS & NS & NS \\
SED \pm & 2.20 & 1.70 & 1.76 \\
AMF & & & \\
Without AMF & 29.4 & 17.05 & 19.52 \\
With AMF & 36.8 & 33.06 & 31.55 \\
& $* *$ & $* *$ & $* *$ \\
SED \pm & 2.20 & 1.70 & 1.76 \\
Varieties & & & \\
NERICA 1 & $25.7 \mathrm{~cd}$ & $22.36 \mathrm{bc}$ & $31.55 \mathrm{a}$ \\
NERICA 2 & $31.5 \mathrm{bc}$ & $25.79 \mathrm{~b}$ & $27.58 \mathrm{ab}$ \\
NERICA 3 & $45.3 \mathrm{a}$ & $18.83 \mathrm{c}$ & $22.89 \mathrm{bc}$ \\
NERICA 4 & $39.1 \mathrm{ab}$ & $35.29 \mathrm{a}$ & $28.00 \mathrm{ab}$ \\
WAB 56-104 & $35.6 \mathrm{~b}$ & $25.97 \mathrm{~b}$ & $24.29 \mathrm{bc}$ \\
Moroberekan & $21.3 \mathrm{~d}$ & $22.08 \mathrm{bc}$ & $18.88 \mathrm{c}$ \\
& $* *$ & $* *$ & $*$ \\
Stress status $\times$ AMF & NS & NS & NS \\
Stress status $\times$ Varieties & NS & NS & NS \\
AMF $\times$ Varieties & NS & NS & NS \\
Stress status $\times$ AMF $\times$ Varieties & NS & NS & NS \\
\hline
\end{tabular}

Means with the same alphabets are non-significantly different using Duncan Multiple Range Test (DMRT) at $5 \%$ level of significant. * means significant at $5 \%$ probability level, **means significant at $1 \%$ probability level.

Table 2 indicated that percentage AM colonisation $(39.87 \%)$ was significantly $(P<0.05)$ higher in crops inoculated with AMF alone than others, the least $(P<0.05)$ was observed in crops with no nutrient source $(16.26 \%)$. 'NERICA 4' had the highest percentage AM colonisation (49.35\%), with the least significant observed in 'Moroberekan' (19.95\%).

Table 2: Effect of nutrient sources on \% AM colonisation of upland 'NERICA' rice.

\begin{tabular}{ll}
\hline Treatments & \% AM colonisation \\
\hline Nutrient Sources & 39.87 \\
AMF & 36.91 \\
AMF $+60 \mathrm{~kg} \mathrm{~N}+30 \mathrm{~kg} \mathrm{~K}$ & 26.10 \\
$60 \mathrm{~kg} \mathrm{~N}+30 \mathrm{~kg} \mathrm{~K}$ & 16.26 \\
Control & $* *$ \\
& 2.233 \\
SED \pm & $22.38 \mathrm{c}$ \\
Varieties & $31.91 \mathrm{~b}$ \\
NERICA 1 & $21.48 \mathrm{c}$ \\
NERICA 2 & $49.35 \mathrm{a}$ \\
NERICA 3 & $33.63 \mathrm{~b}$ \\
NERICA 4 & $19.95 \mathrm{c}$ \\
WAB 56-104 & $* *$ \\
Moroberekan & \\
&
\end{tabular}

Means with the same alphabets are non-significantly different using Duncan Multiple Range Test (DMRT) at $5 \%$ level of significant. * means significant at $5 \%$ probability level, **means significant at $1 \%$ probability level. 
In the screen house, across all growth stages all upland rice grown in unstressed pot had significantly $(P<0.05)$ longer panicle (Table 3$)$. Similar pattern was observed on number of grains per panicle, 100 seed mass and yield per plant across all growth stages (Tables 4, 5 and 6). Inoculation of upland rice with AMF gave significantly $(P<0.05)$ longer panicle than without AMF. This was observed across all growth stages except at vegetative stage, where there was no significant effect of AMF inoculation on panicle length. Significant varietal variability on panicle length was observed at vegetative and grain filling stage, except at reproductive stage, where no significant effect was observed. At vegetative growth stage, 'NERICA 2' had significantly longer panicle $(29.87 \mathrm{~cm})$, however most other varieties had similar panicle length. It was observed that at grain filling stage, 'NERICA 4' had significantly longer panicle with most varieties having no significant differences among them.

Table 3: Effect of moisture stress at different growth stages on panicle length $(\mathrm{cm})$ of upland 'NERICA' rice inoculated with AMF

\begin{tabular}{llll}
\hline Treatments & $\begin{array}{l}\text { Vegetative } \\
\text { phase }\end{array}$ & $\begin{array}{l}\text { Reproductive } \\
\text { phase }\end{array}$ & $\begin{array}{l}\text { Grain-filling } \\
\text { phase }\end{array}$ \\
\hline Stress status & & & \\
unstressed & 26.20 & 25.66 & 26.18 \\
stressed & 23.05 & 12.22 & 10.54 \\
& $* *$ & $* *$ & $* *$ \\
SED \pm & 0.76 & 1.25 & 0.85 \\
AMF & & & \\
Without AMF & 24.90 & 14.96 & 13.68 \\
With AMF & 24.35 & 22.92 & 23.03 \\
& NS & $* *$ & $* *$ \\
SED \pm & 0.76 & 1.25 & 0.85 \\
Varieties & & & \\
NERICA 1 & $23.93 \mathrm{bc}$ & 19.37 & $16.18 \mathrm{c}$ \\
NERICA 2 & $29.87 \mathrm{a}$ & 19.74 & $20.49 \mathrm{ab}$ \\
NERICA 3 & $23.79 \mathrm{bc}$ & 17.02 & $16.34 \mathrm{c}$ \\
NERICA 4 & $21.29 \mathrm{c}$ & 20.51 & $22.10 \mathrm{a}$ \\
WAB 56-104 & $23.06 \mathrm{bc}$ & 19.84 & $17.46 \mathrm{bc}$ \\
Moroberekan & $25.80 \mathrm{~b}$ & 17.15 & $17.58 \mathrm{bc}$ \\
Stress status $\times$ AMF & $* *$ & NS & $* *$ \\
Stress status $\times$ Varieties & $* *$ & $* *$ & $* *$ \\
AMF $\times$ Varieties & NS & NS & $* *$ \\
Stress status $\times$ AMF $\times$ Varieties & $* *$ & $*$ & $* *$ \\
\hline
\end{tabular}

Means with the same alphabets are non-significantly different using Duncan Multiple Range Test (DMRT) at $5 \%$ level of significant. * means significant at $5 \%$ probability level, ** means significant at $1 \%$ probability level.

Inoculated upland 'NERICA' rice grown in the screen house had significantly higher 100 seed mass, higher yield per plant across all growth stages than non-inoculated except number of seeds per panicle, where a conserve pattern was observed with non-inoculated crops having a significantly higher number of seeds per panicle (Tables 4, 5 and 6). On the field significant difference among the nutrient sources were observed in terms of panicle, grains per panicle, 100 grain mass and grain yield ha ${ }^{-1}$ (Table 7). Combination of AMF + $60 \mathrm{~kg} \mathrm{~N} \mathrm{ha}^{-1}+30 \mathrm{Kg} \mathrm{K} \mathrm{ha}^{-1}$ produced significantly higher grain yield and its components compared to other nutrient sources. Conversely, control had significantly the least panicle length $(17.48 \mathrm{~cm})$ and grain yield $\mathrm{ha}^{-1}\left(1.53 \mathrm{t} \quad \mathrm{ha}^{-1}\right)$. 
Yield and its attributes responses ... rice to different nutrient supplying treatments in rainforest transitory agroecology

Table 4: Effect of moisture stress at different growth stages on grains per panicle of upland 'NERICA' rice inoculated with AMF

\begin{tabular}{llll}
\hline Treatments & Vegetative phase & Reproductive phase & Grain-filling phase \\
\hline Stress status & & & \\
unstressed & 298 & 292 & 290 \\
stressed & 221 & 70 & 48 \\
& $*$ & $* *$ & $* *$ \\
SED \pm & 32.80 & 27.90 & 25.80 \\
AMF & & & \\
Without AMF & 394 & 243 & 231 \\
With AMF & 125 & 120 & 108 \\
& $* *$ & $* *$ & $* *$ \\
SED \pm & 32.80 & 27.90 & 25.80 \\
Varieties & & & \\
NERICA 1 & $248 \mathrm{~b}$ & 186 & $170 \mathrm{~b}$ \\
NERICA 2 & $373 \mathrm{a}$ & 283 & $275 \mathrm{a}$ \\
NERICA 3 & $292 \mathrm{ab}$ & 169 & $158 \mathrm{~b}$ \\
NERICA 4 & $176 \mathrm{~b}$ & 135 & $126 \mathrm{~b}$ \\
WAB 56-104 & $237 \mathrm{~b}$ & 167 & $136 \mathrm{~b}$ \\
Moroberekan & $229 \mathrm{~b}$ & 148 & $149 \mathrm{~b}$ \\
& $* *$ & NS & $* *$ \\
Stress status $\times$ AMF & NS & $* *$ & $*$ \\
Stress status $\times$ Varieties & NS & $*$ & NS \\
AMF $\times$ Varieties & NS & NS & NS \\
Stress status $\times$ AMF $\times$ Varieties & NS & NS & NS \\
\hline
\end{tabular}

Means with the same alphabets are non-significantly different using Duncan Multiple Range Test (DMRT) at $5 \%$ level of significant. * means significant at $5 \%$ probability level, ** means significant at $1 \%$ probability level.

Table 5: Effect of moisture stress at different growth stages on 100 grain mass (g) of upland 'NERICA' rice inoculated with AMF

\begin{tabular}{llll}
\hline Treatments & Vegetative phase & Reproductive phase & Grain-filling phase \\
\hline Stress status & & & \\
unstressed & 3.22 & 4.47 & 3.37 \\
stressed & 2.63 & 1.82 & 1.56 \\
& $* *$ & $* *$ & $* *$ \\
SED \pm & 0.11 & 1.19 & 0.11 \\
AMF & & & \\
Without AMF & 2.50 & 1.68 & 1.45 \\
With AMF & 3.34 & 4.61 & 3.48 \\
& $* *$ & $*$ & $* *$ \\
SED \pm & 0.11 & 1.19 & 0.11 \\
Varieties & & & \\
NERICA 1 & $3.23 \mathrm{a}$ & 2.40 & $2.44 \mathrm{bc}$ \\
NERICA 2 & $2.88 \mathrm{a}$ & 2.46 & $2.57 \mathrm{~b}$ \\
NERICA 3 & $3.22 \mathrm{a}$ & 2.28 & $2.18 \mathrm{bc}$ \\
NERICA 4 & $3.02 \mathrm{a}$ & 3.43 & $3.08 \mathrm{a}$ \\
WAB 56-104 & $2.82 \mathrm{a}$ & 6.12 & $2.42 \mathrm{bc}$ \\
Moroberekan & $2.36 \mathrm{~b}$ & 2.16 & $2.13 \mathrm{c}$ \\
& $* *$ & NS & $*$ \\
Stress status $\times$ AMF & $* *$ & NS & NS \\
Stress status $\times$ Varieties & NS & NS & NS \\
AMF $\times$ Varieties & $*$ & NS & NS \\
Stress status $\times$ AMF $\times$ Varieties & NS & NS & NS \\
\hline
\end{tabular}

Means with the same alphabets are non-significantly different using Duncan Multiple Range Test (DMRT) at $5 \%$ level of significant. * means significant at $5 \%$ probability level, ** means significant at $1 \%$ probability level. 
Table 6: Effect of moisture stress at different growth stages on yield per plant (g/plant) of upland 'NERICA' rice inoculated with AMF

\begin{tabular}{|c|c|c|c|}
\hline Treatments & Vegetative phase & Reproductive phase & Grain-filling phase \\
\hline $\begin{array}{l}\text { Stress status } \\
\text { unstressed } \\
\text { stressed }\end{array}$ & $\begin{array}{l}18.32 \\
13.56 \\
* *\end{array}$ & $\begin{array}{l}18.60 \\
8.47 \\
* *\end{array}$ & $\begin{array}{l}18.24 \\
7.01 \\
* *\end{array}$ \\
\hline $\begin{array}{l}\mathrm{SED} \pm \\
\mathrm{AMF}\end{array}$ & 0.99 & 0.91 & 1.05 \\
\hline $\begin{array}{l}\text { Without AMF } \\
\text { With AMF }\end{array}$ & $\begin{array}{l}10.29 \\
21.60 \\
* *\end{array}$ & $\begin{array}{l}6.13 \\
20.94 \\
* *\end{array}$ & $\begin{array}{l}5.96 \\
19.29 \\
* *\end{array}$ \\
\hline $\begin{array}{l}\mathrm{SED} \pm \\
\text { Varieties }\end{array}$ & 0.99 & 0.91 & 1.05 \\
\hline NERICA 1 & 12.66 & $15.46 \mathrm{ab}$ & $14.11 b$ \\
\hline NERICA 2 & 16.71 & $14.30 \mathrm{~b}$ & $18.50 \mathrm{a}$ \\
\hline NERICA 3 & 17.44 & $8.90 \mathrm{c}$ & $8.47 \mathrm{~d}$ \\
\hline NERICA 4 & 17.17 & $18.14 \mathrm{a}$ & $11.62 \mathrm{bcd}$ \\
\hline WAB 56-104 & 16.02 & $14.16 \mathrm{~b}$ & $12.97 \mathrm{bc}$ \\
\hline Moroberekan & $\begin{array}{l}15.65 \\
\text { NS }\end{array}$ & $\begin{array}{l}10.24 \mathrm{c} \\
*\end{array}$ & $\begin{array}{l}10.07 \mathrm{~cd} \\
\mathrm{NS}\end{array}$ \\
\hline Stress status $\times$ AMF & NS & NS & NS \\
\hline Stress status $\times$ Varieties & NS & $*$ & $* *$ \\
\hline $\mathrm{AMF} \times$ Varieties & $* *$ & $*$ & NS \\
\hline Stress status $\times$ AMF $\times$ Varieties & NS & $*$ & NS \\
\hline
\end{tabular}

Means with the same alphabets are non-significantly different using Duncan Multiple Range Test (DMRT) at $5 \%$ level of significant. * means significant at $5 \%$ probability level, ** means significant at $1 \%$ probability level.

Significant varietal variability was observed on all the yield components and grain yield $\mathrm{ha}^{-1}$ on the field (Table 7). Most 'NERICA' rice together with 'WAB 56-104' had no significant differences on panicle length except 'NERICA 4' that had the least panicle length $(19.66 \mathrm{~cm})$ that was not significantly different from 'Moroberekan'.
'Moroberekan' had significantly the least grain per panicle (74.70), 100 grain mass $(2.50 \mathrm{~g})$ and grain yield ha ${ }^{-1}\left(1.22 \mathrm{t} \mathrm{ha}^{-1}\right)$. 'NERICA 1' and 'NERICA 2 ' had significantly higher grain per panicle, 100 grain mass and grain yield $\mathrm{ha}^{-1}$ than other varieties. Other 'NERICAs' occupied intermediate position for yield and components.

Table 7: Effect of nutrient sources on yield and its components of upland NERICA rice

\begin{tabular}{|c|c|c|c|c|}
\hline Treatments & $\begin{array}{l}\text { Panicle length } \\
(\mathrm{cm})\end{array}$ & Grain/panicle & $\begin{array}{l}100 \text { grain mass } \\
(\mathrm{g})\end{array}$ & $\begin{array}{l}\text { Grain Yield } \\
\text { (t/ha) }\end{array}$ \\
\hline \multicolumn{5}{|l|}{ Nutrient Sources } \\
\hline $\mathrm{AMF}$ & $21.46 \mathrm{c}$ & $80.70 b$ & $2.63 b$ & $2.51 \mathrm{a}$ \\
\hline $\mathrm{AMF}+60 \mathrm{~kg} \mathrm{~N}+30 \mathrm{~kg} \mathrm{~K}$ & $25.92 \mathrm{a}$ & $106.60 \mathrm{a}$ & $3.07 \mathrm{a}$ & $2.54 \mathrm{a}$ \\
\hline $60 \mathrm{~kg} \mathrm{~N}+30 \mathrm{~kg} \mathrm{~K}$ & $23.82 b$ & $81.30 \mathrm{~b}$ & $3.07 \mathrm{a}$ & $2.41 \mathrm{a}$ \\
\hline CONTROL & $\begin{array}{l}17.48 \mathrm{~d} \\
*\end{array}$ & $\begin{array}{l}91.20 \mathrm{~b} \\
*\end{array}$ & $\begin{array}{l}2.69 \mathrm{~b} \\
* *\end{array}$ & $\begin{array}{l}1.53 b \\
* *\end{array}$ \\
\hline \multicolumn{5}{|l|}{ Varieties } \\
\hline NERICA 1 & $22.64 \mathrm{ab}$ & $102.9 \mathrm{a}$ & $3.07 \mathrm{a}$ & $2.89 \mathrm{a}$ \\
\hline NERICA 2 & $24.09 \mathrm{a}$ & $98.40 \mathrm{ab}$ & $2.72 \mathrm{ab}$ & $2.90 \mathrm{a}$ \\
\hline NERICA 3 & $22.66 \mathrm{ab}$ & $92.30 \mathrm{abc}$ & $2.83 \mathrm{ab}$ & $2.53 \mathrm{~b}$ \\
\hline NERICA 4 & $19.66 \mathrm{c}$ & $86.40 \mathrm{bcd}$ & $2.83 \mathrm{ab}$ & $2.19 \mathrm{c}$ \\
\hline WAB 56-104 & $23.13 \mathrm{a}$ & $85.00 \mathrm{~cd}$ & $2.83 \mathrm{ab}$ & $1.68 \mathrm{~d}$ \\
\hline Moroberekan & $\begin{array}{l}20.83 b c \\
* *\end{array}$ & $\begin{array}{l}74.70 \mathrm{~d} \\
* *\end{array}$ & $\begin{array}{l}2.50 \mathrm{~b} \\
*\end{array}$ & $\begin{array}{l}1.22 \mathrm{e} \\
* *\end{array}$ \\
\hline $\begin{array}{l}\text { Varieties } \times \text { Nutrient } \\
\text { sources }\end{array}$ & $* *$ & $* *$ & NS & NS \\
\hline
\end{tabular}

Means with the same alphabets are non-significantly different using Duncan Multiple Range Test (DMRT) at $5 \%$ level of significant. * means significant at $5 \%$ probability level, $* *$ means significant at $1 \%$ probability level. 


\section{DISCUSSION}

Results obtained in this investigation indicated a reduction in yield attributes of lowland rice cultivars subjected to soil moisture stress at different growth stages. Response of crop to stress is dependent on its intensity, timing and duration (Bray, 1997; Robertson and Holland, 2004). The pattern observed in the yield attributes investigated indicated that the most pronounced depression was noticed when soil moisture stress was imposed at the reproductive growth stage. This observation is consistent with earlier observations (Liu et al., 2006), where it was noticed that the most susceptible growth stage of rice to abiotic stressor is at this stage. AMF colonisation of the host rice plant under soil moisture deficit at all growth stages was similar with unstressed rice. This pattern of response to water deficit among all the cultivars of rice investigated could have suggested that they must have devised other mechanisms to ameliorate the negative impact of water deficit on them. Most crops were able to avoid soil moisture stress by increasing the volume of soil they could capture water from through increased root volume. Hyphae of AMF had been reported to increase root volume of crops under moisture deficit (Koide, 1993). Similar pattern was also observed here albeit not significant. Other reasons could be the condition where the AMF inoculation was carried out in the pot which could not preclude the possibility of confounding effects of other microbes in the screen house. Significant reduction in grain yield per plant under soil moisture deficit could have been attributed to the reduced yield components of upland rice cultivars.

All the yield attributes of upland rice were significantly affected by inoculation with AMF when stressed at different growth stages except panicle length when soil moisture stress was imposed at vegetative growth stage. This positive effect of AM inoculation on all the yield attributes of upland rice cultivars subjected to soil moisture stress at different growth stages could have contributed to the significant effect of AMF inoculation on grain yield per plant. Earlier reports had indicated a compensatory relationship between number and mass of grains under abiotic stressors (Squire, 1990). The mass of kernel is mostly conserved at the expense of the reduction in its number. This experiment was able to indicate that percentage reduction in number of grains per panicle was more pronounced when upland rice cultivars were subjected to soil moisture stress at vegetative growth stage than subsequent growth stages irrespective of inoculation status. It is possible that vegetative growth stage is a period when the reproductive structures were established or alternatively incidence of water stress at vegetative growth stage would compromise dry matter (Boonjungand \& Fukai, 1996) that would later be remobilized when reproductive structures would be established. Other explanation could be that moisture stress at this growth stage would reduce amount of assimilate that would be sufficient for the host plant and the fungi. In the presence of competition for assimilates at this growth stage establishment of reproductive growth structure would be grossly compromised subsequently. These speculations need further empirical evidences to establish its validity. Increase in grain yield per plant when upland rice cultivars were subjected to soil moisture stress at reproductive and grain filling growth stages were similar in treatments with and without the AMF inoculation. This is consistent with our earlier suggested argument on the availability of assimilates for host-fungi interaction and colonisation. Subsequent incidence of water deficit would be offset by the exploration of soil volume by the fungi hyphae to improve crop water status. AMF response to soil fertilization is dependent on the soil nutrient gradient and host nutrient status (Treseder and Allen, 2002). Several studies had been conducted in the past on the effect of different combinations, especially NPK on AMF colonization (Hepper, 1983; Rajeshkannan et al., 2009; Treseder and Allen, 2002). One common trend was that increased $\mathrm{P}$ fertiliser depresses AMF root colonisation (Jensen and Jakobsen, 1980). Conversely $\mathrm{N}$ and $\mathrm{K}$ fertilization induces inoculation potential (Furlan and Bernier-Cardou, 1989). However, combination of $\mathrm{N}$ and $\mathrm{K}$ on inoculation potential varies with the host plant and fertility status of the soil (Treseder and Allen, 2002). The fertility status of the soil under which the investigation was conducted would be referred to as low according to the fertility classification criteria for Nigerian soils proposed by (Adepeju et al., 2015). The only nutrient that was in sufficient quantity among the macronutrients was $\mathrm{P}$, which 
could have justified the choice of treatment combinations. In this trial on the field, it was observed that combination of AMF $+60 \mathrm{~kg} \mathrm{~N}+30$ $\mathrm{kg} \mathrm{K}$ resulted in significantly higher yield attributes of upland rice cultivars than other combinations in this trial. This was subsequently reflected in the grain yield ha ${ }^{-1}$. Report had earlier indicated that symbiotic association of AMF with host plant is capable of increasing sink strength of the host through simulation of assimilate export to the fungi and increased carbon assimilation (Kaschuk et al., 2009). K was also cited in the literature to be involved in the production (Liebhardt, 1968; Trolldenier, 1972) and transportation (Epstein, 1972) of the assimilate to the fungus. This could increase root colonisation and alter other physiological processes of the inoculated crop positively. $\mathrm{N}$ was implicated in increasing reducing sugar, amino acid composition and infectivity by the fungi (Ratnayake et al., 1978). This combination of AMF with inorganic N and $\mathrm{K}$ could have acted synergistically in this agroecology to simulate yield attributes of upland rice cultivars. However, significant differences in grain yield were not observed among the treatments except control with significantly lower grain yield than others. From a sustainable production of lowland rice perspective, it would appear justifiable to apply only AMF to increase grain yield in this agroecology. Since a comparable yield could be obtained when other more economically and environmentally unsustainable nutrient combinations are used.

Significant varietal differences were observed on the percentage root colonization when upland rice cultivars were subjected to soil moisture stress at all growth stages in the screen house. Similar pattern was observed on the field. 'NERICA 4' displayed significantly higher root colonisation than other upland rice cultivars when subjected to soil moisture stress at all growth stages in both trials. This response pattern in 'NERICA 4' could have predisposes it towards better acclimation to soil moisture stress at all growth stages. Root colonization by AM could extend the root volume and increase the uptake of available water at lower soil depth (Osonubi et al., 1992). This observation could be comparatively advantageous at the most sensitive period to water deficit (reproductive and grain filling growth stages), as reflected in the significantly longer panicle and 100 grain mass observed in 'NERICA 4' than other upland rice cultivars when subjected to soil moisture stress at grain filling stage. However this improved yield attributes could only translate to significantly higher grain yield per plant observed in NERICA 4 cultivar than others when subjected to soil moisture deficit at the reproductive growth stage. It could be hypothesized that other factors could be limiting grain yield per plant when soil moisture stress was imposed at other growth stages. A significantly higher grain yield per plant observed in 'NERICA 2' when subjected to soil moisture stress at grain filling stage could have been attributed to higher number of grains per panicle when stressed at vegetative and grain filling stages and significantly longer panicle when stressed at vegetative growth stage compared to other upland rice cultivars. This finding was validated on the field despite the similarities in the yield components among the upland rice varieties except number of grains per panicle, which was observed to be significantly higher in 'NERICA 1' than others.

\section{CONCLUSION}

Across all growth stages, yield and its components were higher $(P<0.05)$ in upland rice sown in unstressed than water stressed condition. Conversely \% AM colonisation of upland rice experienced a non-significant increase under water stress condition. In both trials AM colonisation was higher $(P<0.05)$ in inoculated upland rice than non-inoculated ones. In the screen house inoculated upland rice had higher $(P<0.05)$ grain yield per plant and its components than noninoculated, except number of grains per panicle when stressed across all growth stages. On the field combination of AMF $+60 \mathrm{~kg} \mathrm{~N} \mathrm{ha}^{-1}+30 \mathrm{~kg}$ $\mathrm{K}$ ha $^{-1}$ produced higher $(P<0.05)$ reproductive growth. Varietal variability $(P<0.05)$ was observed on AM colonisation and reproductive growth in both trials, with 'NERICA 2' been most promising in terms of grain yield ha ${ }^{-1}$. 


\section{ACKNOWLEDGEMENT}

This project was funded by Agricultural Research

Council of Nigeria, under RFA 4.20 of 2011.

\section{REFERENCES}

Abbott, L. K., Robson, A. D., Boer, G. de. (1984). The effect of phosphorus on the formation of hyphae in soil by vesicular-arbuscular mycorrhizal fungus, Glomus fasciculatum. New Phytologist, 97(3), 437446. doi:10.1111/j.1469-8137.1984.tb03609.x

Adepeju, J., Adetunji, M., Ige, D. (2015). Soil-test data interpretation and fertiliser recommendation. In Soil fertility and crop nutrition (pp. 428-452). Ringroad, Ibadan: Jumak Publishers.

Allison, L., Bollen, W. B., Moodie, C. D. (1965). Total carbon. Methods of Soil Analysis. Part 2. Chemical and Microbiological Properties, (methodsofsoilanb), 1346-1366.

Augé, R. M. (2001). Water relations, drought and vesicular-arbuscular mycorrhizal symbiosis. Mycorrhiza, 11(1), 3-42. doi: $10.1007 /$ s005720100097

Augé, R. M. (2004). Arbuscular mycorrhizae and soil/plant water relations. Canadian Journal of Soil Science, 84(4), 373-381. doi:10.4141/S04-002

Awotoye, O. O., Atayese, M. O., Osonubi, O., Mulongoy, K., Okali, D. U. U. (1992). Response of some tropical nitrogen-fixing woody legumes to drought and inoculation with mycorrhiza. Biological Nitrogen Fixation and Sustainability of Tropical Agriculture. K. Mulongoy, M. Gueye and DSC Spencer (eds.) Pp, 67-75.

Azcón, R., Marin, A. D., Barea, J. M. (1978). Comparative role of phosphate in soil or inside the host on the formation and effects of endomycorrhiza. Plant and Soil, 49(3), 561-567. doi:10.1007/BF02183281

Boonjung, H., \& Fukai, S. (1996). Effects of soil water deficit at different growth stages on rice growth and yield under upland conditions. 2. Phenology, biomass production and yield. Field Crops Research, 48(1), 47-55. doi:10.1016/03784290(96)00039-1

Bouyoucos, G. J. (1962). Hydrometer method improved for making particle size analyses of soils. Agronomy Journal, 54(5), 464-465. doi:10.2134/agronj1962.00021962005400050028x

Boyer, L. R., Brain, P., Xu, X.M., Jeffries, P. (2014). Inoculation of drought-stressed strawberry with a mixed inoculum of two arbuscular mycorrhizal fungi: effects on population dynamics of fungal species in roots and consequential plant tolerance to water deficiency. Mycorrhiza, 25(3), 215-227. doi:10.1007/s00572-014-0603-6

Bray, E. A. (1997). Plant responses to water deficit. Trends in Plant Science, 2(2), 48-54. doi:10.1016/S1360-1385(97)82562-9

Defoer, T., Wopereis, M. C., Jones, M., Lancon, F., Erenstein, O., Guei, R. (2004). Rice-based production systems for food security and poverty alleviation in sub-Sahara Africa. IRC Newsletter, $53,85-96$.

Epstein, E. (1972). Mineral nutrition of plants: principles and perspectives., $412 \mathrm{pp}$.

Fjelde, H., von Uexkull, N. (2012). Climate triggers: Rainfall anomalies, vulnerability and communal conflict in Sub-Saharan Africa. Political Geography, 31(7), 444-453. doi:10.1016/j.polgeo.2012.08.004

Franson, R. L., Brown, M. S., Bethlenfalvay, G. J. (1991). The Glycine-Glomus-Bradyrhizobium symbiosis. XI. Nodule gas exchange and efficiency as a function of soil and root water status in mycorrhizal soybean. Physiologia Plantarum, 83(3), $\quad 476-482 . \quad$ doi:10.1111/j.13993054.1991.tb00123.x

Furlan, V., Bernier-Cardou, M. (1989). Effects of N, P, and $\mathrm{K}$ on formation of vesicular-arbuscular mycorrhizae, growth and mineral content of onion. Plant and Soil, 113(2), 167-174. doi:10.1007/BF02280177

Giovannetti, M., Mosse, B. (1980). An evaluation of techniques for measuring vesicular arbuscular mycorrhizal infection in roots. New Phytologist, 84(3), 489-500. doi:10.1111/j.14698137.1980.tb04556.x

Hayman, D. S., Johnson, A. M., Ruddlesdin, I. (1975). The influence of phosphate and crop species on Endogone spores and vesicular-arbuscular mycorrhiza under field conditions.Plant and Soil, 43(1-3), 489-495. doi:10.1007/BF01928510

Hepper, C. M. (1983). The effect of nitrate and phosphate on the vesicular-arbuscular mycorrhizal 
infection of lettuce. New Phytologist, 93(3), 389399. Doi:10.1111/j.1469-8137.1983.tb03439.x

Hoagland, D. R., Arnon, D. I. (1950). The water-culture method for growing plants without soil. Circular. California Agricultural Experiment Station, 347( $2^{\text {nd }}$ ed. $), 32$ pp.

International Rice Research Institute. (2002). Standard Evaluation System. Manila, Philippines: IRRI.

Jackson, M. (1962). Soil chemical analysis. New Delhi: Prentice Hall of India Pvt, Ltd.

Jayne, B., Quigley, M. (2013). Influence of arbuscular mycorrhiza on growth and reproductive response of plants under water deficit: a meta-analysis. Mycorrhiza, 24(2), 109-119. doi:10.1007/s00572013-0515-x

Jensen, A., Jakobsen, I. (1980). The occrrence of vesicular-arbuscular mycorrhiza in barley and wheat grown in some Danish soils with different fertilizer treatments. Plant and Soil, 55(3), 403414. doi:10.1007/BF02182701

Jones, M. P. (1997). Interspecific hybridization: progress and prospects. WARDA.

Jones, M. P., Dingkuhn, M., Aluko, G. K., Semon, M.,. (1997). Interspecific Oryza sativa L. x $O$. glaberrima Steud. progenies in upland rice improvement. Euphytica, 94(2), 237-246. doi:10.1023/A:1002969932224

Kaschuk, G., Kuyper, T. W., Leffelaar, P. A., Hungria, M., Giller, K. E. (2009). Are the rates of photosynthesis stimulated by the carbon sink strength of rhizobial and arbuscular mycorrhizal symbioses? Soil Biology and Biochemistry, 41(6), 1233-1244. doi:10.1016/j.soilbio.2009.03.005

Koide, R. T. (1993). Physiology of the mycorrhizal plant. Advances in Plant Pathology, 9, 33-54.

Koide, R. T., Robichaux, R. H., Morse, S. R., \& Smith, C. M. (1989). Plant water status, hydraulic resistance and capacitance. In Plant physiological ecology (pp. 161-183). Springer. doi:10.1007/97894-009-2221-1_9

Liebhardt, W. (1968). Effect of potassium on carbohydrate metabolism and translocation. In V. Kilmer, S. Younts, \& N. Brady (Eds.), The role of potassium in Agriculture (pp. 147-164). Madison, Wisconsin: ASA-CSSA-SSSA.

Linares, O. F. (2002). African rice (Oryza glaberrima): History and future potential. Proceedings of the National Academy of Sciences, 99(25), 1636016365. doi:10.1073/pnas.252604599
Liu, A., Hamel, C., Hamilton, R. I., Ma, B. L., Smith, D. L. (2000). Acquisition of $\mathrm{Cu}, \mathrm{Zn}, \mathrm{Mn}$ and $\mathrm{Fe}$ by mycorrhizal maize (Zea mays L.) grown in soil at different $\mathrm{P}$ and micronutrient levels. Mycorrhiza, 9(6), 331-336. doi:10.1007/s005720050277

Liu, J. X., Liao, D. Q., Yang, X. E., Li, Z. C., Bennett, J. (2006). Genetic variation in the sensitivity of anther dehiscence to drought stress in rice. Field Crops Research, 97(1), 87-100. doi:10.1016/j.fcr.2005.08.019

McGonigle, T. P., Miller, M. H., Evans, D. G., Fairchild, G. L., Swan, J. A. (1990). A new method which gives an objective measure of colonization of roots by vesicular-arbuscular mycorrhizal fungi. New Phytologist, 495-501. doi:10.1111/j.14698137.1990.tb00476.x

McLean, E. (1982). Soil pH and lime requirements. In: A. Page, R. Miller, and R. Keneey (Eds.), Methods of soil analysis ( $2^{\text {nd }}$ ed., pp. 199-223). Agronomy Society of America.

Miller, R. M., Jastrow, J. D. (1994). Vesiculararbuscular mycorrhizae and biogeochemical cycling. Mycorrhizae and Plant Health. APS Press, The American Phytopathological Society, St. Paul, Minnesota, 189-213.

Murphy, J., Riley, J. P. (1952). A modified single solution method for determination of phosphate uptake by rye. Soil Science Society of America Proceedings. 48, 31-36.

Noyd, R. (1965). Ecological interactions between native prairie grass and AMF in the reclamation of ore tailing. University of Minnesota, St Paul, MN.

Oikeh, S. O., Nwilene, F. E., Agunbiade, T. A., Oladimeji, O., Ajayi, O., Mande, S., Samejima, H. (2008). Growing upland rice: a production handbook. Africa Rice Center (WARDA). http://www.fao.org/fileadmin/user_upload/ivc/docs/ uplandrice.pdf

Olsen, S., Dean, L. (1965). Methods of Soil Analysis. In: C. Black (Ed.), Phosphorus (Vol. 9, pp. 10351049). Madison, WI: American Society of Agronomy Inc.

Osonubi, O., Bakare, O. N., Mulongoy, K. (1992). Interactions between drought stress and vesiculararbuscular mycorrhiza on the growth of Faidherbia albida (syn. Acacia albida) and Acacia nilotica in sterile and non-sterile soils. Biology and Fertility of Soils, 14(3), 159-165. doi:10.1007/BF00346056

Phillips, J. M., Hayman, D. S. (1970). Improved procedures for clearing roots and staining parasitic and vesicular-arbuscular mycorrhizal fungi for rapid assessment of infection. Transactions of the 
Yield and its attributes responses ... rice to different nutrient supplying treatments in rainforest transitory agroecology

British Mycological Society, 55(1), 158-IN18. doi:10.1016/S0007-1536(70)80110-3

Rajeshkannan, V., Sumathi, C. S., Manian, S. (2009). Arbuscular mycorrhizal fungi colonization in upland rice as influenced by agrochemical application. Rice Science, 16(4), 307-313. doi:10.1016/S1672-6308(08)60095-5

Rapparini, F., Peñuelas, J. (2014). Mycorrhizal Fungi to Alleviate Drought Stress on Plant Growth. In M. Miransari (Ed.), Use of Microbes for the Alleviation of Soil Stresses, Volume 1 (pp. 21-42). Springer New York. doi:10.1007/978-1-4614-9466-9_2

Ratnayake, M., Leonard, R. T., Menge, J. A. (1978). Root exudation in relation to supply of phosphorus and its possible relevance to mycorrhizal formation. New Phytologist, 81(3), 543-552. doi:10.1111/j.1469-8137.1978.tb01627.x

Rillig, M. C. (2004). Arbuscular mycorrhizae, glomalin, and soil aggregation. Canadian Journal of Soil Science, 84(4), 355-363. doi:10.4141/S04-003

Robertson, M., \& Holland, J. (2004). Production risk of canola in the semi-arid tropics of Australia. Australian Journal of Agricultural Research, 55, 526-538. doi:10.1071/AR03219

Smith, S., Read, D. (2008). Mycorrhizal Symbiosis, Third Edition ( ${ }^{\text {rd }}$ edition). Amsterdam; Boston: Academic Press.

Squire, G. (1990). The physiology of tropical crop production. Wallingford, UK: CABI.
Sumner, M. E., Farina, M. P. (1986). Phosphorus interactions with other nutrients and lime in field cropping systems. In Advances in soil science (pp. 201-236). Springer. doi:10.1007/978-1-4613-8660$5 \_5$

Sylvia, D. M., Neal, L. H. (1990). Nitrogen affects the phosphorus response of VA mycorrhiza. New Phytologist, 303-310. doi:10.1111/j.14698137.1990.tb00456.x

Treseder, K. K., Allen, M. F. (2002). Direct nitrogen and phosphorus limitation of arbuscular mycorrhizal fungi: a model and field test. New Phytologist, 155(3), 507-515. doi:10.1046/j.14698137.2002.00470.x

Trolldenier, G. (1972). L'influence de la nutrition potassique de haricots nains (Phaseolus vulgaris var. nanus) sur l'exudation de substances organiques marquees au ${ }^{14} \mathrm{C}$, le nombre de bacteries rhizospheriques et la respiration des racines. Review of Ecological Biology, 9, 595-603.

Walkley, A., Black, I. A. (1934). An examination of the Degtjareff method for determining soil organic matter, and a proposed modification of the chromic acid titration method. Soil Science, 37(1), 29-38. doi:10.1097/00010694-193401000-00003

Yoshida, S., \& Hasegawa, S. (1982). The rice root system: its development and function. Drought Resistance in Crops with Emphasis on Rice, 10. 